ఠ

\title{
Regarding optical coherence tomography grading of ischemia in central retinal venous occlusion
}

\section{Koushik Tripathy}

Department of Vitreoretina and Uvea, ICARE Eye Hospital \& Postgraduate Institute, Noida, Uttar Pradesh, India
Correspondence: Koushik Tripathy ICARE Eye Hospital \& Postgraduate Institute, E3A, Sector-26, Noida,

Uttar Pradesh, India, 20I30I

Tel +9l I20 2555969

Email drkoushiktripathy@icarehospital.org
This article was published in the following Dove Press journal:

Clinical Ophthalmology

22 February 2017

Number of times this article has been viewed

\section{Dear editor}

The author read with interest the article by Browning et al. ${ }^{1}$ The author humbly wants to discuss a few facts.

1. The article ${ }^{1}$ discusses grading of retinal ischemia based on optical coherence tomography features in central retinal venous occlusion. As coexisting central retinal arterial occlusion or cilioretinal arterial occlusion may also cause inner retinal hyper-reflectivity, exclusion of such cases is an important consideration before implicating central retinal venous occlusion for the ischemia. Extensive intraretinal hemorrhages are other important hindrances to the evaluation of the perfusion status of the retina using both fluorescein angiogram and optical coherence tomography.

2. It would be interesting to know the gonioscopic findings, especially neovascularization of the anterior chamber angle if it was performed at presentation and during the follow-ups.

3. The manuscript documented that the incidence of anterior segment neovascularization at 1 year was $8.9 \%$ in severe ischemia group. ${ }^{1}$ The incidence of anterior segment neovascularization in perfused groups was higher $(15.4 \%$ and $17.6 \%$ for mild and moderate ischemia, respectively). Although the sample size was low, such findings are contrary to the literature ${ }^{2}$ and require further discussion.

\section{Disclosure}

The author reports no conflicts of interest in this communication.

\section{References}

1. Browning DJ, Punjabi OS, Lee C. Assessment of ischemia in acute central retinal vein occlusion from inner retinal reflectivity on spectral domain optical coherence tomography. Clin Ophthalmol. 2017;11:71-79.

2. A randomized clinical trial of early panretinal photocoagulation for ischemic central vein occlusion. The Central Vein Occlusion Study Group N report. Ophthalmology. 1995;102(10):1434-1444. 


\section{Authors' reply \\ David J Browning \\ Omar S Punjabi \\ Chong Lee}

Department of Ophthalmology, Charlotte Eye, Ear, Nose and Throat Associates, PA, Charlotte, NC, USA

Correspondence: David J Browning

Department of Ophthalmology, Charlotte Eye, Ear, Nose and Throat

Associates, PA, 6035 Fairview Rd, Charlotte, NC 28210, USA

Tel +l 7042953180

Fax +l 7042953186

Email dbrowning@ceenta.com

\section{Dear editor}

We thank Dr Tripathy for his interest in our article and would respond to his above-mentioned points.

1. We agree that excluding eyes with cilioretinal artery and central retinal artery occlusions is necessary to be able to attribute inner retinal reflectivity changes to central retinal vein occlusion. Cilioretinal artery occlusion is associated with a band of ischemic retinal whitening and central retinal artery occlusion more generalized posterior-pole ischemic whitening. Neither was present in any of our patients. The changes in inner retinal reflectivity were present without visible whitening.

The confounding effects of intraretinal hemorrhage were recognized and accounted for as found in the following sentence in "Methods" section: "When there was concomitant intraretinal hemorrhage, the grading was done based on a zone without intraretinal hemorrhage if one was present, but if intraretinal hemorrhage was confluent, the inner retina was hyperreflective and delineation of layers was obscured by the hemorrhage, such cases were graded as severe ischemia".

2. This was a retrospective study drawn from two retina specialists (DJB and OSP). There was no standardization about when gonioscopy was performed. Therefore, the development of anterior segment neovascularization (ASNV) may have been underestimated relative to a figure derived from a systematic prospective study in which gonioscopy would be uniformly performed before pupillary dilation.

3. The incidence of ASNV recorded in Table 2 of the manuscript was confounded by the frequent injection of antivascular endothelial growth factor drugs for macular edema in all three groups. As we wrote in the "Discussion" section: "The frequent injection of antiVEGF drugs not only treated the macular edema but also probably masked any underlying associations of ASNV and NVG with baseline ischemia".

We thank him for his interest and comments.

\section{Disclosure}

The authors report no conflicts of interest in this communication.

Dove Medical Press encourages responsible, free and frank academic debate. The content of the Clinical Ophthalmology 'letters to the editor' section does not necessarily represent the views of Dove Medical Press, its officers, agents, employees, related entities or the Clinical Ophthalmology editors. While all reasonable steps have been taken to confirm the content of each letter, Dove Medical Press accepts no liability in respect of the content of any letter, nor is it responsible for the content and accuracy of any letter to the editor.

Clinical Ophthalmology

\section{Publish your work in this journal}

Clinical Ophthalmology is an international, peer-reviewed journal covering all subspecialties within ophthalmology. Key topics include: Optometry; Visual science; Pharmacology and drug therapy in eye diseases; Basic Sciences; Primary and Secondary eye care; Patient Safety and Quality of Care Improvements. This journal is indexed on

Submit your manuscript here: http://www.dovepress.com/clinical-ophthalmology-journal

\section{Dovepress}

PubMed Central and CAS, and is the official journal of The Society of Clinical Ophthalmology (SCO). The manuscript management system is completely online and includes a very quick and fair peer-review system, which is all easy to use. Visit http://www.dovepress.com/ testimonials.php to read real quotes from published authors. 